\title{
Coronavirus infection has reached Brazil, what now? Nurses' emotions
}

\author{
A infecção por coronavírus chegou ao Brasil, e agora? Emoções de enfermeiras e enfermeiros \\ La infección por coronavirus ha llegado en Brasil, ¿y ahora? Emociones de enfermeras y enfermeros
}

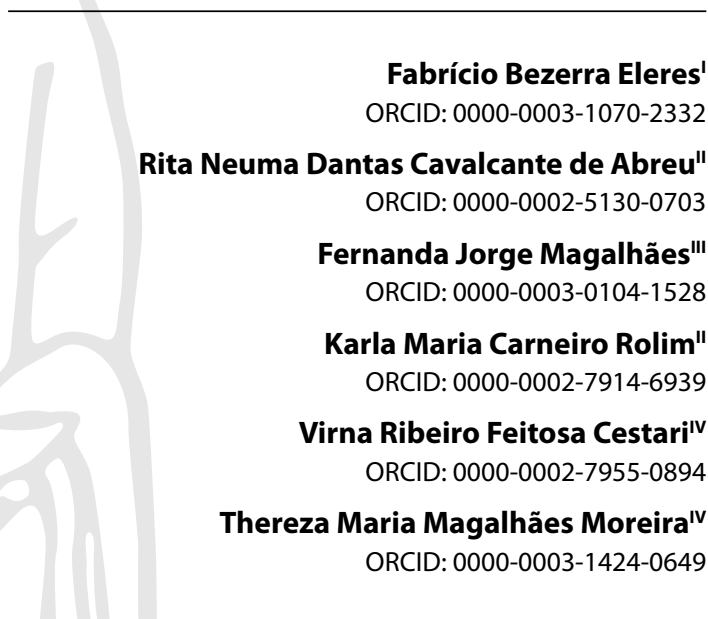

'Faculdade dos Carajás. Marabá, Pará, Brazil. "Universidade de Fortaleza. Fortaleza, Ceará, Brazil. I'Universidade de Pernambuco. Recife, Pernambuco, Brazil. "Universidade Estadual do Ceará. Fortaleza, Ceará, Brazil.

How to cite this article:

Eleres FB, Abreu RNDC, Magalhães FJ, Rolim KMC Cestari VRF, Moreira TMM. Coronavirus infection has reached Brazil, what now? Nurses' emotions. Rev Bras Enferm. 2021;74(Suppl 1):e20201154. https://doi.org/10.1590/0034-7167-2020-1154

Corresponding author:

Rita Neuma Dantas Cavalcante de Abreu E-mail: rita_neuma@yahoo.com.br

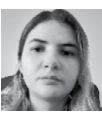

EDITOR IN CHIEF: Dulce Barbosa ASSOCIATE EDITOR: Antonio José de Almeida Filho

Submission: $11-24-2020$

Approval: 03-10-2021

\section{ABSTRACT}

Objective: To investigate the nurse's emotions about coronavirus infection (COVID-19). Method: We conducted a qualitative study with 58 nurses, students of the postgraduate course in Nursing of a higher education institution in Fortaleza, State of Ceará, Brazil. We obtained data through questionnaires with a sociodemographic approach and reflections on the emotions/perceptions of nurses, as well as a synchronous meeting to discuss strategies for worker health during the pandemic. We organized the results on the IRaMuTeQ software with a presentation in figures and speeches. Results: The speeches revealed emotions such as anxiety, tiredness, fear, insecurity, distress, and emotional pain. However, the occurrence of words such as "tranquility" and "wellbeing" emphasize comfort, overcoming, and hope. Final considerations: The Master's degree students showed concern for family members, fear, and anxiety, with requests for actions by people management to promote strategies to minimize and control such emotions.

Descriptors: Coronavirus Infections; Emotions; Mental Health; Nurses; Nursing.

\section{RESUMO}

Objetivo: Investigar as emoções de enfermeiras e enfermeiros acerca da infecção por coronavírus (COVID-19). Método: Estudo qualitativo realizado com 58 enfermeiros discentes do curso de pós graduação em Enfermagem de uma instituição de ensino superior, em Fortaleza/CE, Brasil. Os dados foram obtidos por meio de questionários com abordagem sociodemográfica e reflexões acerca das emoções/percepções dos enfermeiros, além de um encontro síncrono para discussão de estratégias para a saúde do trabalhador durante a pandemia. Os resultados foram organizados no software IRaMuTeQ com apresentação em figuras e falas. Resultados: Os discursos revelaram emoções como: ansiedade, cansaço, medo, insegurança, angústia e dor emocional. Contudo, o aparecimento de palavras como "tranquilidade" e "bem-estar" ressaltam conforto, superação e esperança. Considerações finais: Os mestrandos evidenciaram a preocupação com familiares, medo e ansiedade, com requisição de ações por parte da gestão de pessoas a fim de favorecer estratégias para minimizar e controlar tais emoções.

Descritores: Infecções por Coronavírus; Emoções; Saúde Mental; Enfermeiras e Enfermeiros; Enfermagem.

\section{RESUMEN}

Objetivo: Investigar las emociones de enfermeras y enfermeros acerca de la infección por coronavirus (COVID-19). Método: Estudio cualitativo realizado con 58 enfermeros discentes del curso de postgrado en Enfermería de una institución de enseñanza superior, en Fortaleza/CE, Brasil. Datos obtenidos por medio de encuestas con abordaje sociodemográfico y reflexiones acerca de las emociones/percepciones de los enfermeros, además de un encuentro síncrono para discusión de estrategias a la salud del trabajador durante la pandemia. Los resultados fueron organizados en el software IRaMuTeQ con presentación en figuras y hablas. Resultados: Los discursos revelaron emociones como: ansiedad, fatiga, miedo, inseguridad, angustia y dolor emocional. Sin embargo, el aparecimiento de palabras como "tranquilidad" "bienestar" $^{\text {" }}$ resaltan conforto, superación y esperanza. Consideraciones finales: Los discentes evidenciaron la preocupación con familiares, miedo y ansiedad, con requisición de acciones por parte de la gestión de personas a fin de favorecer estrategias para minimizar y controlar tales emociones. Descriptores: Infecciones por Coronavirus; Emociones; Salud Mental; Enfermeras y Enfermeros; Enfermería. 


\section{INTRODUCTION}

The pandemic of coronavirus infections (COVID-19) remains severe and constantly spreading. Therefore, it was designated as an emergency and International public health problem, with relevant concern from the World Health Organization ${ }^{(1)}$. The current scenario highlights the high risk of contamination by SARS-CoV-2, the causative agent of COVID-19, which generates infection with possible physical and/or psychological consequences in the short, medium, and long term. Health professionals are among the groups of workers most at risk: they are exposed to a greater possibility of contamination and compromise of up to $20 \%$ of their workforce, as found in some European countries - Spain, for example ${ }^{(2-3)}$.

In Brazil, it is estimated that one third of the half of the population exposed to an epidemic may suffer at least one psychopathological manifestation, especially in the lack of specific care interventions. The factors involved in these psychosocial repercussions are related to the magnitude of the epidemic and the degree of vulnerability of individual ${ }^{(4)}$.

Regarding the professionals working as "front line" workers, in constant contact with individuals infected by the SARS-CoV-2 virus ${ }^{(5)}$, today, we can find considerations that the pandemic presents itself as a trigger for acute or post-traumatic stress, depression, insomnia, irritability, anger and even emotional exhaustion $^{(3)}$.

Recently published review studies point out the following emotions as the effects of quarantine: confusion, anger, and even post-traumatic stress. Of these, 24 studies involved professionals working on the "front line," highlighting more than 11 thousand residents and/or medical personnel from areas affected by middle east respiratory syndrome (MERS), severe acute respiratory syndrome (SARS), swine flu (H1N1) or Ebola ${ }^{(6-7)}$.

Faced with the current COVID-19 pandemic, scholars suggest harmful effects on the mental health of undergraduate university students ${ }^{(7)}$, but field studies with postgraduates are still minimal. In this context, we can emphasize that the master's students working in health services during the pandemic face higher vulnerability situations because they experience challenging scenarios.

Attending a master's and, above all, a doctorate course is an arduous task because it involves qualification examination, development, and defense of the dissertation/thesis, participation in events, compliance with the credits of the disciplines, publication of articles in qualified journals, etc. We can include financial difficulties, family, personal, emotional, professional, marital aspects, among others. Frequently, all these challenges together may affect the physical and, above all, the mental health of students ${ }^{(8)}$. From this perspective, a qualitative approach is necessary to identify the emotions of Master's students about COVID-19 infection in Brazil to understand the impacts of the new pandemic in an attempt to minimize its effects.

\section{OBJECTIVE}

To investigate the nurses' emotions about coronavirus infection (COVID-19).

\section{METHODS}

\section{Ethical and legal aspects}

We preserved the identity of the participants replacing their names by alphanumeric codes (E1, E2... E58), as recommended by Resolution $466 / 2016^{(9)}$. The study was approved by the Research Ethics Committee and followed the guidelines of the Consolidated Criteria for Reporting Qualitative Research (COREQ) ${ }^{(10)}$.

\section{Type of study}

Descriptive study with qualitative approach.

\section{Study setting}

It was conducted in a private higher education institution (HEI), in Fortaleza, State of Ceará, Brazil.

\section{Data sources}

The total population invited to the study included nurses over 18 years old, linked to a postgraduate program of the master's course or newly graduated experts who were part of one of its five classes, totaling 118 nurses working in the health system. Sixty-three expert nurses or master's students of the postgraduate program of the $\mathrm{HEl}$ responded to the questionnaire, applying the following inclusion criterion: to be working, face-to-face, in health institutions during the COVID-19 pandemic. Thus, we obtained a final sample of 58 nurses.

\section{Collection and organization of data}

The invitation to participate in the study was sent through WhatsApp because of the time of social distancing, and it was promoted in the five groups of the classes of the Professional Master's degree course. When accepting the invitation, the nurse carefully read the free and informed consent form and checked the acceptance icon, which is mandatory to advance the other information as well as to have access to the questionnaire link, which was prepared through the Google Forms tool. The collection was carried out for a week in July 2020.

As for the questionnaire, it contained questions such as sociodemographic data (gender, age, training time, service time, and professional unit) and reflexive questions about current perceptions, feelings, and emotions due to the pandemic.

After answering this questionnaire, the 58 participants of the study were invited to participate in a synchronous moment through visual and relational communication using a free platform performed by a nurse expert in mental health. To do so, we sent an invitation with date, time, Google Meet access link, and objective of the intervention through WhatsApp of the groups of the five classes of the postgraduate course. Sixteen nurses participated at this moment, in which we sought to intervene with reflection strategies about coping actions in the context of the pandemic, as well as understand how they felt and what measures they used for physical and psycho-emotional coping. 


\section{Data analysis}

To support the textual analysis and relevant themes in the speeches of the 58 participants, we used the R Interface software for multidimensional analyses of texts and Questionnaires (IRaMuTeQ), which consists of a free access program developed in the Python language, using the functionalities of the $R$ statistical software. However, it does from the perspective and qualitative approach, enabling different processing and statistical analysis of the textual corpus, with the elaboration of figures that represent the speeches/words uttered by the study participants ${ }^{(11)}$.

For the analysis of the speeches, we performed a comparison of the answers. Initially, we explored classical textual statistics using basic lexicography and searching for specificities by groups of words. Then, for the multivariate analyses, we opted for Descending Hierarchical Classification (DHC), Similarity Analysis (similarities) and elaboration of the Word Cloud, generated by IRaMuTeQ.

To perform the $\mathrm{DHC}$, we classified the textual segments or elementary context units (ECU) according to their respective words and their higher chi-square values. We used them to verify the Association of ECU with a specific class, and we organized the words in a dendrogram ${ }^{(12-13)}$. Therefore, we understood that all the words selected to compose the classes of the dendrogram had $p<0.001$, indicating a statistically significant association.

Through similarity analysis, we constituted the ideal mathematical model for the study to verify the relationship between discrete objects of any kind with possible identification of co-occurrences between words and facts. These are supported by the theory of graphs and indicate a connection among words and assist in the structure of a textual corpus, distinguishing between the common parts and the particularities of the descriptive variables ${ }^{(13)}$.

That is, it is from the similarity analysis that the common keywords in the speeches of the participants are identified, gathering them in a cloud of grouping words with graphic organization, according to their frequency in speeches. After using IRaMuTeQ, a data processing tool, researchers interpreted the results through a reflective critical reading of evidence available in the literature, shown in figures and statements ${ }^{(14)}$.

\section{RESULTS}

At first, this study data show the characterization and identification of the emotions, perceptions, and feelings demonstrated by master's students in the face of the COVID-19 pandemic. Therefore, the mean age was $36.0 \pm 6.9$ years, with a minimum of 25 years and a maximum of 55 years. The majority of participants had weekly working hours up to $40(37 ; 63.8 \%)$, with a minimum of 30 hours and a maximum of 114 hours.

In a second moment, we present the results of intervention with reflection strategies with nurses about coping actions in the context of the pandemic.

\section{Nurses' emotions, perception, and feelings}

Of the speeches analyzed, 71 ECUs were obtained, using $70.4 \%$ of the textual corpus, defined in six classes, presented in the dendrogram of the DHC (Figure 1) and named according to the specific content of the speeches. The corpus was divided into two subcorpus: the first comprised Classes 1 and 5, which concentrated $14 \%$ and $24 \%$ of ECUs with words that demonstrated emotions and feelings involving family and family moment. The second subcorpus presented Class 6 ( $16 \%$ of ECUs related to fatigue) and Class 4 (14\% of ECUs related to well-being). This last subcorpus suffered a partition, giving rise to Classes 2 and 3 (16\% of UCEs, each) reflecting the words "anxiety" and "tiredness," respectively.

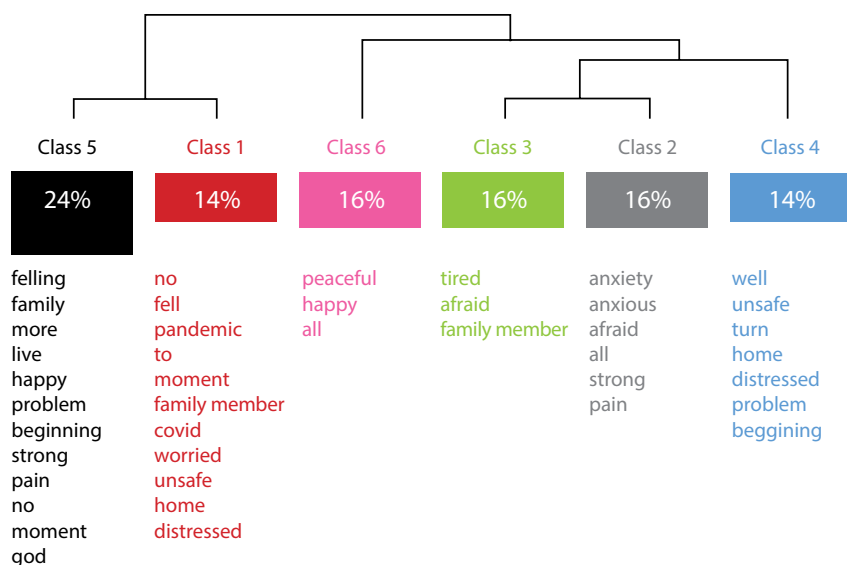

Figure 1 - Dendrogram of the textual corpus and classes referring to the speeches

In the results of the first subcorpus, classes 1 and 5 stand out, showing the nurses' feelings such as concern, tension, and fear in the face of exposure to infection and the possibility of contamination of their family members by COVID-19. The speeches of E3, E15, and E26 demonstrate this feeling:

I am afraid for my family. I'm distressed by the growth of cases in the city of my relatives. (E3)

I always get tense when I return home because I have a son. I take a high risk in the hospital and expose my whole family. (E15)

I'm afraid of bringing the infection to family members who live in my house, afraid of being asymptomatic and infecting everyone. (E26)

In the second subcorpus, which incorporates Classes 2, 3, 4, and 6, we observed other emotions and some negative feelings, such as fear, distress, despair, sadness, frustration, and emotional/ empathic pain, as seen in the statements of E12, E14, E15 and E20.

I live tired and worried, afraid, distressed by what we have gone through. (E12)

Doubts and uncertainties make me worried and unsure about the virus and the future. (E14)

I feel tiredness and fear, sometimes unmotivated. (E15)

I feel physical tiredness and sadness because of the countless deaths. (E20)

However, in Classes 4 and 6, words such as "tranquility" and "well" appear, in the sense of "well-being." Participants highlight positive feelings with the flexibility of thoughts such as comfort 
attitudes, understanding of the current situation, faith, gratitude and self-recognition of their professional function, overcoming and hope as identified in the statements of E11, E14, and E28.

I understand the tough and challenging times. With commitment and wisdom, we will find the solution. I am grateful to have survived and to have contributed to the recovery of many people. (E11)

We are reassuring ourselves and believing that the worst is over. (E14)

I'm sure God is with me. We have to trust in your protection. (E28)

In accordance with DHC and similarity analysis, the results reveal central emotions in the nurses' expression cloud. As the feeling of the great axis, there is the "fear" (mentioned 33 times); in a smaller proportion, axes such as "worried" (mentioned 15 times) and "anxious" (cited 14 times) arise; and, as a peripheral zone of similarity, the term "quiet" (cited 13 times) stands out, as shown in Figure 2.
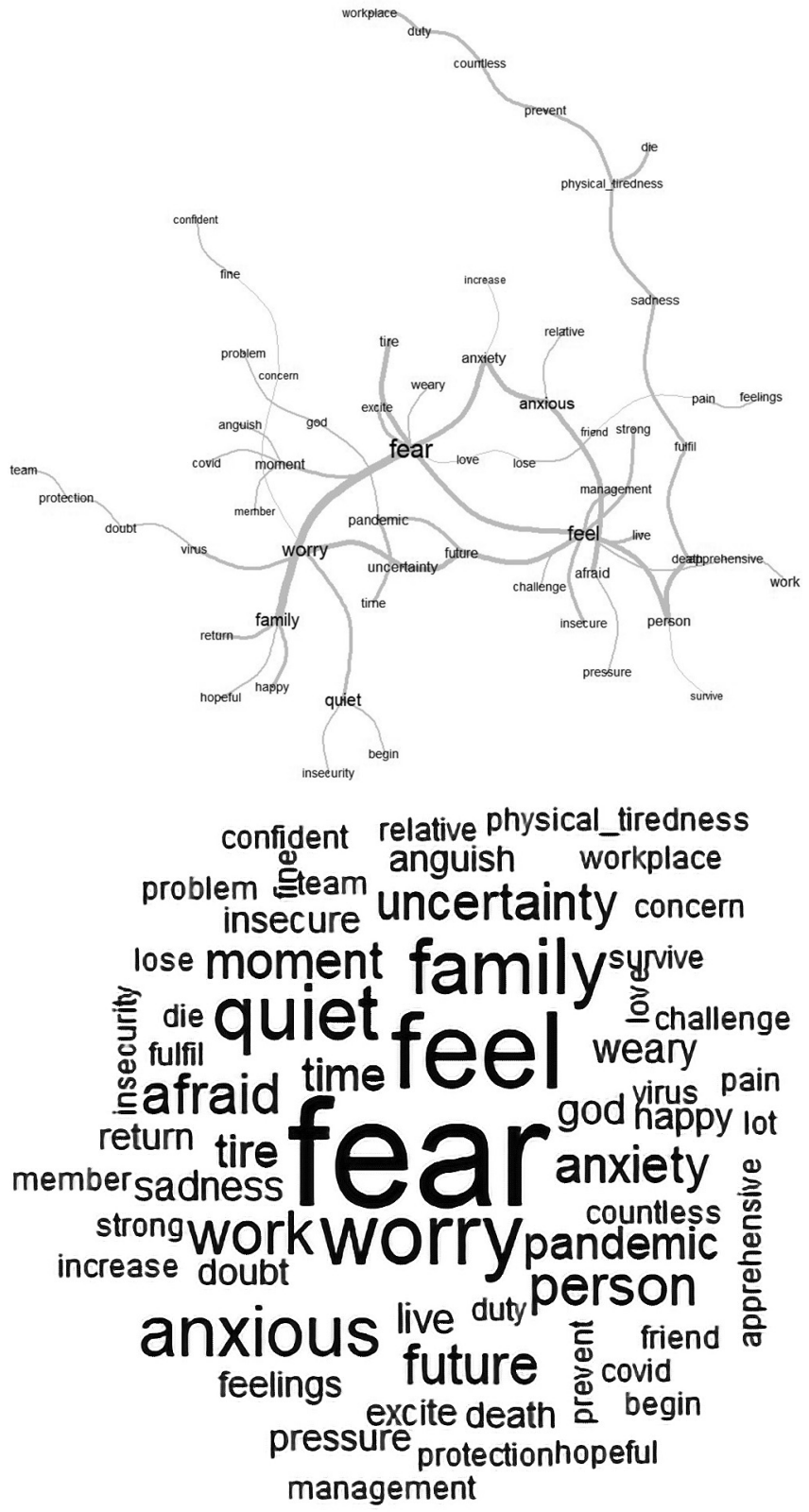

Figure 2 - Cloud and similarity analysis of nurses' emotions/feelings
With the discourses analysis, we noticed that, in the speeches of E1,E12, E25, E26, E49, and E58, there are emotions such as fear, often reported and linked to the various changes caused by COVID-19 in the daily work of these professionals, especially in how to deal with losses. The speeches bring feelings such as insecurity and anxiety before the challenges of a disease on which there is poor scientific basis, unknown, with demands to an inexperienced team. Moreover, they highlight a new form of organization of the care process as well as exhaustive hours of work and poor remuneration because of the circumstances in which they live.

We are losing loved ones, both relatives and friends, very quickly and without the right to watch over the body, situations never experienced, and we will never forget it. I'm distressed with the current situation. We have to practice empathy. (E25)

It is a big challenge, and I do not feel confident in management. (E1)

I'm overwhelmed leading an inexperienced team, fearful for the quality of care provided to patients and for their safety. (E49)

I'm tired and worried about overwork. (E12)

Increasing the working hours to cover colleagues who have been infected causes mental and physical fatigue. Increased responsibility generates nervousness. Increased demands generate anxiety, a race against time that requires us to make quick decisions that sometimes generate insecurity. (E26)

Work on moments of stress and pressure, non-valuation, and non-remuneration adequate to the occupational risk of exposure to COVID. (E58)

Anxiety and concern resulting from uncertainty about the future were feelings present in the statements of E27 and E58.

The pandemic has caused more insecurity and uncertainty about the future. (E27)

A sense of uncertain future. (E58)

However, we observe positive feelings, optimism, and hope in the speeches of E20,E23, and E36, especially regarding doing their best and contributing to people's health.

Moments of sadness and distress in the beginning, but now more confident and optimistic. (E36)

Despite the problems happening in the world, my mood is stable, I'm fine. (E23)

A feeling of duty fulfilled for doing my best within my workplace to prevent more people from dying. (E20)

\section{Intervention as a coping strategy of the emotions, percep- tions and feelings}

After understanding the nurses' emotions, perceptions, and feelings, we realized the need for interventions that could use coping strategies and reduction of negative feelings such as fear and anxiety. 
For this, we prepared a synchronous moment with a dialogued presentation chaired by an expert in psychiatric nursing, entitled "Orientations regarding coping strategies to reduce anxiety."

After recording the feelings and strategies used by nurses to cope with emotions such as anxiety and fear, we noticed by the speeches of E1 and E8 that these reflected on the self-knowledge and importance of identifying their physiological reactions and the warning signs that the body brings in the face of everyday work situations.

It was great to define what kind of feeling we are developing at that moment to know that we are exposed to physiological reactions, and we cannot let them dominate and become pathological. (E1)

It was essential because I could recognize warning signs and have an objective orientation on how to act in the face of moments of anxiety. (E8)

The participants were also able to define this moment as learning intervention, relaxation, and proposal of ideas of actions and/ or strategies for coping with feelings of anxiety, fear, and worry, as reported by E3, E5, and E7.

This learning in breathing techniques and relaxation are always very relevant to me. (E3)

It was a very rewarding, very rich moment of knowledge. (E5)

This synchronous moment was great for us to understand that the mind creates a lot of concern for the future at this time of the pandemic, but we need to criticize the thoughts and see the probability of happening. Mindfulness and the protocol calms you down and helps a lot to reduce anxiety and worry. (E7)

\section{DISCUSSION}

The COVID-19 pandemic determines negative impacts on the economy, on health care in the various spheres, as well as on the mental health of the society ${ }^{(15)}$. Health professionals also often experience stressors in the context of pandemics, which relate, for example, to exhaustion at work, increased exposure, distance from people, among others ${ }^{(5)}$.

In this research, we evidenced nurses' concern with their families in the face of the pandemic of the new coronavirus. Fear, worry, and anxiety were also present in the speeches and terms more frequently in the corpus.

Authors $^{(2)}$ emphasize that nursing, due to the profession's characteristics, is considered a group of professionals who remain with the patient for a longer time during the entire care process. Thus, we should consider its technical aspects, as well as psychosocial and emotional conditions, especially the fear of getting sick, dying, and contaminating their relatives.

Therefore, we corroborated that health professionals experience emotional exhaustion related to the fear of contaminating themselves at work as one of the immediate impacts of professional activity, fear of losing their own life, which is sometimes overcome due to the fear of putting the lives of other people in danger. Such a perspective allows us to think that we live anticipatory mourning, linked to the fear of losing the meaning of life and the existential meaning of one's profession ${ }^{(3)}$.
On the other hand, these professionals revealed, in their speeches, the word "tranquility," highlighting attitudes of overcoming and hope, a sense of duty fulfilled, as well as trust in God. Therefore, it showed agreement with discourses that refer to the importance of spirituality for a sense of hope, the power of professional resilience, attention, appreciation of the person to absorb sense of solidarity, cooperation, and the professional oath based on the premise that "you will love your neighbor as yourself"(16).

Given the context identified in this study, we decided to conduct an orientation moment with encouragement to use actions and coping strategies and reduction of emotions and feelings such as anxiety, fear, and worry.

Thus, we reinforced the importance of self-knowledge and identification of warning signs and manifestations of fear and anxiety presented by the body, a situation that can lead to pathologies. In this context, authors ${ }^{(17)}$ emphasize that the practical way to differentiate anxiety considered normal from anxiety considered pathological is to identify and evaluate whether the anxious reaction is short-lived, self-limited, and related to the stimulus of the moment - characteristics related to the normality pattern.

It is worth noting that the participants also described the importance of self-knowledge and understanding of the breathing technique, the use of mindfulness (total attention technique and mastering your mind), and the calm down protocol to perceive the warning signs and have guidelines at the time of the anxiety crisis (each letter represents a necessary step for the proper management of a situation perceived as threatening or with imminent new bodily sensations of "danger")(18).

\section{Limitations of the study}

A limitation of the study refers to the difficulty of performing an intervention with coping strategies in person and the need for social isolation using a synchronous meeting.

Therefore, we suggest further studies to identify risk factors to the health of these professionals to then intervene in person to promote the worker's health with the use of activities and/or strategies for coping with anxiety, fear, or concern in the face of the daily life work, with the resolution of problems and/or possible traumatic signs identified during and/or after the status of the pandemic.

\section{Contributions to the area}

The nurses' speeches in the context of the COVID-19 pandemic reveal disparate emotions and feelings of those who, even in such conditions, seek to provide quality care with hope and empathy, considering the situation of each health user and their family.

Thus, as a contribution to the practice, to the area of mental health care, worker health, health promotion, and other health care, the study offers an understanding of the central emotions, feelings, and perceptions in the presence of an unknown disease, which imposes the need for isolation, generates devastation, a high number of cases of complications and death, as well as exposure and risks of occupational stress development.

Therefore, given the above, it is necessary to review such situations and develop mechanisms that restructure nursing practice to better working conditions and reducing the harmful effects 
on the mental health of risk groups. Although the professional cannot go through all these stages of care unharmed from some sort of suffering/illness, the manifestation of spirituality aimed at the forces that embrace positivity and the protection of the common good favors the respect for the person/family and resizes the emotions of desolation through empathy and self-giving ${ }^{(16)}$.

\section{FINAL CONSIDERATIONS}

The Master's students showed concern with family members, fear, and anxiety, requesting actions from people management to favor strategies to minimize and control such emotions.
Also, based on the analysis of discourse and similarity of emotions, feelings, and perceptions, a greater frequency of emotions and feelings was found in the textual corpus, such as tiredness, insecurity, distress, and empathic/emotional pain. However, the appearance of words such as "tranquility" and "well-being" reinforce comfort, overcoming, and hope.

Regarding the timing of synchronous intervention, the participants understood the importance of self-knowledge, identification of warning signs, and detection of manifestations to use actions aimed at coping and reducing such feelings. To that end, the most frequent terms were: optimism, confidence, excellence learning, and gratitude.

\section{REFERENCES}

1. Villela DAM. The value of mitigating epidemic peaks of COVID-19 for more effective public health responses. Rev Soc Bras Med Trop. 2020;53:e20200135. https://doi.org/10.1590/0037-8682-0135-2020

2. Barbosa DJ, Gomes MP, Souza FBA, Gomes AMT. Fatores de estresse nos profissionais de Enfermagem no combate à pandemia da COVID-19. Comun Ciênc Saúde [Internet]. 2020 [cited 2020 Jul 10];31(Suppl 1):31-47. Available from: http://www.escs.edu.br/revistaccs/index.php/ comunicacaoemcienciasdasaude/article/view/651

3. Oliveira WA, Cardoso EAO, Silva JL, Santos MA. Impactos psicológicos e ocupacionais das sucessivas ondas recentes de pandemias em profissionais da saúde: revisão integrativa e lições aprendidas. Estud Psicol (Campinas). 2020;37:e200066. https://doi. org/10.1590/1982-0275202037e200066

4. Fundação Osvaldo Cruz (Fiocruz). Saúde Mental e Atenção Psicossocial na Pandemia COVID19 [Internet]. Rio de Janeiro. 2020 [cited 2020 Jul 10]. Available from: https://portal.fiocruz.br/sites/portal.fiocruz.br/files/documentos/cartilha_recomendacoes_gerais_06_04.pdf

5. Schmidt B, Crepaldi MA, Bolze DAS, Silva LN, Demenech LM. Impactos na Saúde Mental e Intervenções Psicológicas Diante da Pandemia do Novo Coronavírus (COVID-19). Estud Psicol (Campinas). 2020;20(1):104-113. https://doi.org/10.1590/1982-0275202037e200063

6. Brooks S, Webster R, Smith L, Woodland L, Wessely S, Greenderg N. The psychological impact of quarantine and how to reduce it: rapid review of the evidence. Lancet. 2020;395(10227):912-92. https://doi.org/10.1016/S0140-6736(20)30460-8

7. Maia BR, Dias PC. Ansiedade, depressão e estresse em estudantes universitários: o impacto da COVID-19. Estud Psicol (Campinas). 2020;37:e200067. https://doi.org/10.1590/1982-0275202037e200067

8. Garcia CE, Nebel L. O quanto vale a dor? Estudo sobre a saúde mental de estudantes de pós-graduação no Brasil. Polis (Santiago). 2018;17(50):207-27. https://doi.org/10.4067/S0718-65682018000200207

9. Conselho Nacional de Saúde. Resolução № 466 de 12 de dezembro de 2012. Dispõe sobre as diretrizes e normas regulamentadoras de pesquisas envolvendo seres humanos. Diário Oficial da União [da] República Federativa do Brasil. Brasília, 2013.

10. Allison T, Peter S, Jonathan C. Consolidated criteria for reporting qualitative research (COREQ): a 32-item checklist for interviews and focus groups. Int J Qual Health Care. 2007;19(6):349-57. https://doi.org/10.1093/intqhc/mzm042

11. Souza MAR, Wall ML, Thuler ACMC, Lowen IMV, Peres AM. The use of IRAMUTEQ software for data analysis in qualitative research. Rev EsC Enferm USP [Internet]. 2018 [cited 2019 Oct 25];52:1-7. Available from: https://www.scielo.br/pdf/reeusp/v52/1980-220X-reeusp-52-e03353.pdf

12. Salvador PTCO, Gomes ATL, Rodrigues CCFM, Chiavone FBT, Alves KYA, Bezerril MS, et al. Uso do software IRAMUTEQ nas pesquisas brasileiras da área da saúde: uma scoping review. Rev Bras Promoç Saúde. 2018;21(Supl.1):1-9. https://doi.org/10.5020/18061230.2018.8645

13. Camargo BV, Justo AM. IRAMUTEQ: um software gratuito para análise de dados textuais. Temas Psicol [Internet]. 2013 [cited 2020 Jul 10];21(2):513-8. Available from: https://www.redalyc.org/pdf/5137/513751532016.pdf

14. Kami MTM, Larocca LM, Chaves MMN, Lowen IMV, Souza VMP, Goto DYN. Working in the street clinic: use of IRAMUTEQ software on the support of qualitative research. Esc Anna Nery[Internet]. 2016 [cited 2020 Sep 25];20(3):e29160069. Available from: https://www.scielo.br/ pdf/ean/v20n3/en_1414-8145-ean-20-03-20160069.pdf

15. Medeiros EAS. Desafios para o enfrentamento da pandemia COVID-19 em hospitais universitários. Rev Paul Pediatr. 2020;38: e2020086. https://doi.org/10.1590/1984-0462/2020/38/2020086

16. Tavares CQ. Dimensões do cuidado na perspectiva da espiritualidade durante a pandemia pelo novo coronavírus (COVID-19). J Health NPEPS [Internet]. 2020 [cited 2020 Jul 10];5(1):1-4. Available from: http://docs.bvsalud.org/biblioref/2020/04/1095168/4517-15943-1-pb.pdf

17. Castillo AR, Recondo R, Asbahr F, Manfro G. Transtornos de ansiedade. Rev Bras Psiquiatr. 2020;22(supl. 2):20-23. https://doi.org/10.1590/ S1516-44462000000600006

18. Range B. Tratamento cognitivo-comportamental para o transtorno de pânico e agorafobia: uma história de 35 anos. Estud Psicol (Campinas). 2008;25(4):477-486. https://doi.org/10.1590/S0103-166X2008000400002 